\title{
Passengers' Perceptions on Effectiveness of Public Facilities in Hasanuddin International Airport Terminal Based on Ordered Logit Model
}

\author{
M. Isran Ramli", Rinto Patandungan ${ }^{*}$, S. Adji Adisasmita ${ }^{\#}$

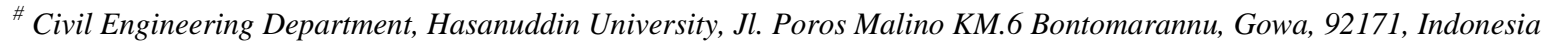 \\ E-mail: isranramli@unhas.ac.id; adjiadisasmita@yahoo.com \\ * Civil Engineering Department, Indonesia Manokwari Institute of Science and Technology, Manokwari, Indonesia \\ E-mail: rintopatadungan@gmail.com
}

\begin{abstract}
The present study attempts to grasp the effectiveness of the public facilities such as waiting rooms, lounge, and cafe in Hasanuddin International Airport terminal, in Makassar City, Indonesia regarding the preferences of the airport passengers. This study collected the passenger's preferences data through an interview survey approach which using a questionnaire sheet instrument. The inquiry involves individual characteristics and travel attributes of passengers. The study used an ordered logit model in analyzing the passenger's preferences. The analysis results show that there are some significant variables which influence the traveler's preferences in the assessment of the effectiveness of the public facilities in the airport. The relevant variables involve airlines, trip frequency, the time interval between arrival time and boarding time, and the place of waiting for boarding time. The passenger's preferences analyzing described that the public facilities at Hasanuddin International Airport are sufficient enough.
\end{abstract}

Keywords - effectiveness; public facilities; Hasanuddin International Airport; ordered logit model.

\section{INTRODUCTION}

Nowadays, most airports in Asian Countries are facing passenger demand increasing rapidly. This phenomenon leads to the airport's operators in the region have to have prepared and improved the service quality of the airports [1]. In this regard, passenger satisfaction and expectations on the airport service quality are the key performance indicators for airport operation management [2]-[4]

In the field of the passenger satisfaction of the airport service quality, many scholars have studied the passengers' perception related to the airport facilities services of the airports in the region. For example, Park and Jung [3] investigated the transfer passenger's preferences addressed to service quality of airport and its influence on value, satisfaction, airport image, and passenger behavior for a case study of Incheon International Airport. Ching [5] researched passengers expected and perceived service and quality satisfaction of the Hong Kong International Airport (HKIA). Chao et al. [2] focused on enhancing airport service quality of Kaohsiung International Airport in Taiwan. Adisasmita [6] studied the performance of airport terminal in SoekarnoHatta International Airport regarding passengers' perception.
Han et al. [7] examined passengers' perceptions on the importance of attributes that determine usage and service quality measurement of airline lounges. Barros et al. [8] evaluated the level of service for transfer passengers at airports. Gonçalves, et al. [9] modeled airport level of service according to departing passenger's perceptions at a small-sized airport. Also, Borille et al. [10] evaluated the level of service arrival components at airports.

Those previous studies utilized some analytical and modeling approaches to exploring the airport passenger perception. The methods involve structural equation modeling [3], statistical description method [5], importanceperformance analysis [6], [11], and a hierarchical approach [11]. Furthermore, Tsaur et al. [12] used fuzzy MCDM in evaluating airline service quality, as well as, Li et al. [13] developed a hybrid approach based on fuzzy AHP and 2tuple fuzzy linguistic method for evaluation in-flight service quality. Additionally, Correia et al. [14] proposed a global index for a level of service evaluation at airport passenger terminals. In the view of the airport facilities as the object of the studies, those studies focused on transfer, departure, and arrival passenger services. Only a few studies which concentrated on the public facilities in an airport terminal, such as public waiting rooms, café, and lounges. However, 
the public services have been playing an essential role in an operating system of an airport terminal. The facilities have functioned as a transition place for the passengers in waiting for their boarding time. In this regard, only Han et al. [7] have focused on passenger perception for the airline lounge facility.

In Asian developing countries, such as Indonesia which has 29 international airports [15], the international airports have provided the public facilities in serving their passengers' need. However, the increasing airport demand rapidly could not be followed by the level of service improvement of the airport facilities. This condition leads to the passenger's satisfaction decreasing [6] and low environmental quality of the airports [16].

Regarding the phenomenon, the present study aims to grasp effectiveness of the public facilities, such as public waiting rooms, café, and lounges of international airports in Indonesia, through a case study on the public facilities in airport terminal of Hasanuddin International Airport in Makassar City. The city is the biggest city in eastern part of Indonesia which has transportation demand increasing rapidly [17], [18]. The effectiveness of the facilities based on the passenger's perception. The study adopts the ordered logit model approach in the assessment of the passenger's perception of the effectiveness of the facilities. The present paper is organized as follows. Section 2 describes the study methods, Section 3 presents the results, and the final section provides conclusions.

\section{MATERIAL AND METHODS}

\section{A. Data Collection}

The present study carried out an interview survey of the passengers in the Hasanuddin International Airport terminal to collect the passenger's perception data. The study utilized a questionnaire sheet which provided question-related to the individual characteristics, the trip characteristics of the passengers, passengers' behaviors in the airport terminal, and passengers' perception of utilizing the public facilities. The variables of each category and indicators or attributes of each variable are provided in Table 1 . In the survey, there were 1,040 passengers selected randomly to interview. The respondents were chosen from six airlines which operated in the airport, such as Lion Air, Garuda Indonesia, Sriwijaya Air, Citilink, Wings Air, and Batik Air.

\section{B. The Ordered Logit Model Structure}

An ordered logit model is applied due to the ordinal nature of the dependent variable [19]. In this study, the ordered logit model was used to examine the influencing factors affecting the airport passenger's perception on the effectiveness of utilization of the public facilities in the terminal building of Hasanuddin International Airport, as the dependent variable with a ranking order. The model structure of the ordered logit model in this study is discussed in more detail below.

$$
Y_{i}=\left\{\begin{array}{l}
\text { 0: The public facilities are very less effective } \\
\text { 1: The public facilities are less effective } \\
\text { 2: The public facilities are effective enough } \\
\text { 3:The public facilities are effective } \\
\text { 4:The public facilities are very effective }
\end{array}\right.
$$

\begin{tabular}{|c|c|c|c|c|c|}
\hline \multirow{3}{*}{\begin{tabular}{c}
\multicolumn{1}{c}{ Variables } \\
Airline companies
\end{tabular}} & \multirow{3}{*}{\begin{tabular}{|c|} 
Symbol \\
$X_{1}$
\end{tabular}} & \multicolumn{4}{|c|}{ Atributes } \\
\hline & & a. Lion Air & b. Garuda & c. Sriwijaya Air & d. Citilink \\
\hline & & e. Wings Air & f. Batik Air & & \\
\hline \multicolumn{6}{|l|}{ Individual characteristics } \\
\hline Sex & $X_{2}$ & a. Male & b. Female & & \\
\hline \multirow[t]{3}{*}{ Occupation } & \multirow[t]{3}{*}{$\mathrm{X}_{3}$} & a. Civil Servant & $\begin{array}{l}\text { b. Gov. Own } \\
\text { Comp. }\end{array}$ & $\begin{array}{l}\text { c. Military/ } \\
\text { Police }\end{array}$ & d. Teacher \\
\hline & & e. Lecturer & \begin{tabular}{|l} 
f. Private \\
Employee \\
\end{tabular} & g. Entrepreneur & h. Student \\
\hline & & i. Housewife & j. Others & & \\
\hline \multirow[t]{2}{*}{ Age (Years old) } & \multirow[t]{2}{*}{$\mathrm{X}_{4}$} & a. $<20$ & b. $20-30$ & c. $31-40$ & d. $41-50$ \\
\hline & & e. $51-60$ & f. $>60$ & & \\
\hline \multirow{2}{*}{$\begin{array}{l}\text { Income per-month } \\
\left(\text { IDR } 1 \times 10^{6}\right)\end{array}$} & $\mathrm{X}_{5}$ & a. $<1.5$ & b. $1.5-3.0$ & c. $3.0-4.5$ & d. $4.5-6.0$ \\
\hline & & e. $6.0-7.5$ & f. $7.5-9.0$ & g. $>9.0$ & \\
\hline \multicolumn{6}{|l|}{ Trip characteristics } \\
\hline Pickups available & $X_{6}$ & a. Yes & b. No & & \\
\hline \multirow[t]{2}{*}{ Trip purposes } & \multirow[t]{2}{*}{$\mathrm{X}_{7}$} & a. Task & $\begin{array}{l}\text { b. Business/ } \\
\text { Occupation }\end{array}$ & $\begin{array}{l}\text { c. Holiday/ } \\
\text { Recreation }\end{array}$ & d. Education \\
\hline & & \begin{tabular}{|l|l|} 
e. Family \\
\end{tabular} & f. Others & & \\
\hline \multirow{2}{*}{$\begin{array}{l}\text { Trip frequency in a year } \\
\text { (Times) }\end{array}$} & \multirow[t]{2}{*}{$\mathrm{X}_{8}$} & a. $1-2$ & b. 3 - 4 & c. $5-6$ & d. $7-8$ \\
\hline & & e. $9-10$ & f. $11-12$ & g. $13-14$ & h. $>14$ \\
\hline \multirow{2}{*}{$\begin{array}{l}\text { Number of trip mate } \\
\text { (Person) }\end{array}$} & \multirow[t]{2}{*}{$\mathrm{X}_{9}$} & a. 0 & b. 1 & c. 2 & d. 3 \\
\hline & & e. 4 & f. 5 & g. 6 & h. $>6$ \\
\hline \multirow[t]{2}{*}{ Cabin bag types } & $X_{10}$ & a. Suitcase & b. Backpack & c. Sling & d. Handbag \\
\hline & & e. Crackle bag & f. Cardboard & g. Others & \\
\hline \multicolumn{6}{|c|}{ Passenger's behaviours in the airport terminal } \\
\hline $\begin{array}{l}\text { After check in, is passenger } \\
\text { direct to waiting room? }\end{array}$ & $\mathrm{X}_{11}$ & a. Yes & b. No & & \\
\hline Check-in methods & $\mathrm{X}_{12}$ & a. Online & b. Counter & c. Group & d. Represented \\
\hline \multirow{2}{*}{$\begin{array}{l}\text { Arrival time headway from } \\
\text { boarding time (Minutes) }\end{array}$} & \multirow[t]{2}{*}{$X_{13}$} & a. 30 & b. $30-60$ & c. $60-90$ & d. $90-120$ \\
\hline & & e. $120-150$ & f. $>150$ & & \\
\hline \multirow[t]{2}{*}{$\begin{array}{l}\text { Waiting place for boarding } \\
\text { time }\end{array}$} & \multirow[t]{2}{*}{$\mathrm{X}_{14}$} & $\begin{array}{l}\text { a. Public waiting } \\
\text { room }\end{array}$ & b. Café & $\begin{array}{l}\text { c. Souvenir } \\
\text { shop }\end{array}$ & $\begin{array}{l}\text { d. Reflection } \\
\text { place }\end{array}$ \\
\hline & & $\begin{array}{l}\text { e. Around waiting } \\
\text { room }\end{array}$ & f. Lounge & g. Others & \\
\hline \multicolumn{6}{|c|}{ Passenger's preferences in utilizing public facilities } \\
\hline \multirow{2}{*}{$\begin{array}{l}\text { Effectiveness of public } \\
\text { waiting room }\end{array}$} & \multirow[t]{2}{*}{$\mathrm{Y}_{1}$} & a. Very effective & b. Effective & \multicolumn{2}{|c|}{ c. Effective enough } \\
\hline & & d. Less effective & e. Very less ef & ective & \\
\hline \multirow[t]{2}{*}{ Effectiveness of café } & $\mathrm{Y}_{2}$ & a. Very effective & b. Effective & c. Effective enou & \\
\hline & & d. Less effective & e. Very less eff & ective & \\
\hline Effectiveness of lounge & $\mathrm{Y}_{3}$ & a. Very effective & b. Effective & c. Effective enou & \\
\hline & & d. Less effective & e. Very less eff & Tective & \\
\hline
\end{tabular}

TABLE I

THE PASSENGER'S CHARACTERISTICS

$\mathrm{Y}$ is not quantity but a ranking, thus, a more considerable value of $\mathrm{Y}$ means more, or better. In this case, there are a known natural number $m$ such that

$$
P\left[Y_{i} \in\{0,1,2 \ldots m\}\right]=1
$$

The data type is usually modelled via a latent (unobserved) variable model:

Where:

$$
Y_{i}^{* \prime}=\alpha\left|\beta_{i}^{\prime} X_{i}\right| \varepsilon
$$

$Y_{i}^{*}:$ a latent (unobserved) measure of the effectiveness of public facilities in the airport terminal which revealed by the respondents.

' $X$ : a vector of explanatory variables describing the passenger's characteristics, trip characteristics of the passengers, and the passenger's behaviors in the airport terminal.

$\alpha_{i}, \beta_{i}$ : the vectors of parameters to be estimated which denotes as a random error term (it assumed to follow a standard normal distribution for probit model or logistic distribution for logit model). This study followed the logistic distribution. 
The observed and coded discrete passenger's perception variable, $Y_{i}$ is determined from the model as follows (e.g., for the facilities effectiveness model):

$$
Y_{i}=\left\{\begin{array}{l}
0 \rightarrow: \text { Very less effective if } Y^{*} \leq 0 \\
1 \rightarrow: \text { Less effective if } 0<Y^{*} \leq \mu_{1} \\
2 \rightarrow: \text { Effective enough if } \mu_{1}<Y^{*} \leq \mu_{2} \\
3 \rightarrow: \text { Effective if } \mu_{2}<Y^{*} \leq \mu_{3} \\
4 \rightarrow: \text { Very effective if } Y^{*} \geq \mu_{3}
\end{array}\right.
$$

Where: $\mu_{i}$ represents the thresholds to be estimated along with the parameter vector $\beta_{i}$.

The probability associated with the coded responses of an ordered probability model is as follows:

$$
\begin{aligned}
& P_{r}\left(Y_{i}=j\right)=P_{r}\left(\mu_{j-1}<Y_{i}^{*} \leq \mu_{j}\right) \\
& =P_{r}\left(\mu_{j-1}<\left[\alpha+\beta_{t}{ }^{\prime} X_{i}+\varepsilon\right] \leq \mu_{j}\right)
\end{aligned}
$$

As the random error $\varepsilon$ should be distributed, the function will be

$$
\begin{aligned}
& P_{r}\left(Y_{i}=j\right)=P_{r}\left(\mu_{j-1}<Y_{i}^{*} \leq \mu_{j}\right) \\
& =F\left(\mu_{j}-\alpha-\beta_{i}^{\prime} X_{i}\right)-F\left(\mu_{j-1}-\alpha-\beta_{i}{ }^{\prime} X_{i}\right)
\end{aligned}
$$

In ordered logit, $F(x)$ is specified as the logistic distribution function, i.e.

$$
F(x)=\exp (x) /[1+\exp (x)]
$$

\section{RESULTS AND DISCUSSION}

\section{A. The Passenger Characteristics}

Table 2 shows the characteristics of the passengers such as sex, occupation, age, and income. Mostly airplane companies have passengers a little bit more male than female, and exception Batik Air has passengers which majority male than female. The passengers of all airplanes have majority occupation as a private employee, entrepreneur, civil servant, and housewife. The age categories of the passengers are dominated by $31-40$ years old, 41 - 50 years old, and 21 - 30 years old, respectively. However, there are a little bit portions of the passengers which have age less than 20 years old. A majority of the passengers have income around $3-4.5$ million rupiahs. Then, it is followed by the passengers who have income categories around 4.5 - 6 million rupiahs, and less than 1.5 million rupiahs, in most similar portion. Regarding the income characteristics, later on, this study focuses on the three majority income categories of the passengers for the perception analysis, i.e., less than 3 million rupiahs, $3-4.5$ million rupiahs, and more than 4.5 million rupiahs.

\section{B. The Trip Characteristics of the Passengers}

Table 3 shows the summary of the passenger survey related to the trip characteristics of the passengers such as pickups available, trip purposes, trip frequency, the number of trip mate, and the cabin bag types of the passengers. There is mostly similar portion between the passengers which have pickups in conducting their travel from an origin place to the airport and do not have pickups. Regarding the trip purposes of the passengers, the majority of passengers have the trip purpose for business or occupation. Then, it is followed by the passenger portions which have trip purposes

\begin{tabular}{|c|c|c|c|c|c|c|}
\hline \multirow{2}{*}{$\begin{array}{c}\text { Passenger's } \\
\text { Characteristics }\end{array}$} & \multicolumn{6}{|c|}{ Percentage of each attributes of the variables for the airlines (\%) } \\
\hline & Lion Air & Garuda & Sriwijaya Air & Citilink & Wings Air & Batik Air \\
\hline \multicolumn{7}{|c|}{ 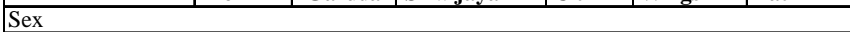 } \\
\hline Male & 51.73 & 59.75 & 50.91 & 58.59 & 54.55 & 72.73 \\
\hline Female & 48.27 & 40.25 & 49.09 & 41.41 & 45.45 & 27.27 \\
\hline \multicolumn{7}{|l|}{ Occupation } \\
\hline Civil Servant & 16.17 & 17.43 & 23.64 & 16.16 & 19.19 & 22.73 \\
\hline Gov. Own & 3.23 & 7.88 & 0 & 7.07 & 4.04 & 9.09 \\
\hline Military/Police & 4.85 & 2.9 & 0 & 3.03 & 3.03 & 4.55 \\
\hline Teacher & 7.85 & 2.07 & 0 & 5.05 & 5.05 & 0 \\
\hline Lecturer & 3.93 & 6.64 & 2.73 & 9.09 & 7.07 & 9.09 \\
\hline Private Employee & 24.48 & 15.35 & 31.82 & 24.24 & 24.24 & 18.18 \\
\hline Entrepreneur & 17.32 & 26.56 & 19.09 & 14.14 & 18.18 & 18.18 \\
\hline Student & 6.24 & 9.13 & 9.09 & 8.08 & 9.09 & 9.09 \\
\hline Housewife & 14.55 & 11.2 & 13.64 & 13.13 & 10.1 & 9.09 \\
\hline Others & 1.39 & 0.83 & 0 & 0 & 0 & 0 \\
\hline \multicolumn{7}{|l|}{ Age (Years old) } \\
\hline$<20$ & 4.39 & 3.73 & 0 & 9.09 & 3.03 & 4.55 \\
\hline $20-30$ & 25.64 & 23.24 & 32.73 & 14.14 & 26.26 & 18.18 \\
\hline $31-40$ & 45.96 & 36.93 & 49.09 & 49.49 & 41.41 & 45.45 \\
\hline $41-50$ & 21.02 & 34.44 & 18.18 & 27.27 & 29.29 & 31.82 \\
\hline $51-60$ & 3 & 1.66 & 0 & 0 & 0 & 0 \\
\hline$>60$ & 0 & 0 & 0 & 0 & 0 & 0 \\
\hline \multicolumn{7}{|c|}{ Income per-month (IDR $\left.1 \times 10^{6}\right)$} \\
\hline$<1.5$ & 20.32 & 15.35 & 13.64 & 22.22 & 18.18 & 18.18 \\
\hline $1.5-3.0$ & 12.01 & 2.49 & 16.36 & 21.21 & 9.09 & 4.55 \\
\hline $3.0-4.5$ & 40.42 & 34.85 & 29.09 & 27.27 & 44.44 & 36.36 \\
\hline $4.5-6.0$ & 20.09 & 22.82 & 24.55 & 24.24 & 21.21 & 18.18 \\
\hline $6.0-7.5$ & 4.39 & 6.22 & 10 & 3.03 & 7.07 & 13.64 \\
\hline $7.5-9.0$ & 2.77 & 13.69 & 6.36 & 1.01 & 0 & 9.09 \\
\hline$>9.0$ & 0 & 4.56 & 0 & 1.01 & 0 & 0 \\
\hline
\end{tabular}
for task, family, education, and holiday or recreation, respectively. Mostly the passengers have flight frequency in a year around $3-4$ times, and $5-6$ times.

TABLE II

THE PASSENGER'S CHARACTERISTICS

\section{The Passenger's Behaviors in the Airport Terminal}

This study attempted to capture three passenger's behaviors in the airport terminal, i.e., the activities of the passengers after they conducted check-in process, the passenger's check-in methods, the passenger's arrival time headway from their boarding time, and their place in waiting boarding time. Those passengers' behaviors are shown in Table 4. Regarding Table 4, mostly the passengers continue their activities directly to the waiting room after their conducted check-in process. The majority of the passengers carried out their check-in process using check-in at the counters. However, there was a significant portion of the passengers which conducted check-in process using online method. Regarding the time interval between the arrival time and the boarding time of the passengers, mostly the passengers have interval time of $30-60$ minutes. There were also the significant amount of the passengers who have interval time of $60-90$ minutes. Furthermore, the majority of the passengers chose public waiting room, as well as café, as waiting place for their boarding time. Even though, the passenger's proportion which choosing public waiting room is larger than choosing café. Also, there were proportion enough of the passenger which chose the lounges in the airport terminal as their waiting place. 
TABLE III

THE TRIP CHARACTERISTICS OF THE PASSENGERS

\begin{tabular}{|c|c|c|c|c|c|c|}
\hline \multirow{2}{*}{$\begin{array}{l}\text { Trip characteristics } \\
\text { of the passengers }\end{array}$} & \multicolumn{6}{|c|}{ Percentage of each attributes of the variables for the airlines $(\%)$} \\
\hline & Lion Air & Garuda & Sriwijaya Air & Citilink & Wings Air & Batik Air \\
\hline \multicolumn{7}{|c|}{ Pickups available } \\
\hline Yes & 43.42 & 50.21 & 57.27 & 29.29 & 36.36 & 36.36 \\
\hline No & 56.58 & 49.79 & 42.73 & 70.71 & 63.64 & 63.64 \\
\hline \multicolumn{7}{|l|}{ Trip purposes } \\
\hline Task & 26.56 & 31.12 & 24.55 & 24.24 & 19.19 & 31.82 \\
\hline Business/Occupation & 35.80 & 34.02 & 45.45 & 29.29 & 26.26 & 27.27 \\
\hline Holiday/Recreation & 11.09 & 13.28 & 1.82 & 14.14 & 10.10 & 9.09 \\
\hline Education & 12.70 & 11.62 & 6.36 & 13.13 & 13.13 & 9.09 \\
\hline Family & 13.63 & 9.96 & 21.82 & 19.19 & 31.31 & 22.73 \\
\hline \begin{tabular}{|l|l} 
Others \\
\end{tabular} & \begin{tabular}{|r|}
0.23 \\
\end{tabular} & 0.00 & 0.00 & 0.00 & 0.00 & 0.00 \\
\hline \multicolumn{7}{|c|}{ Trip frequency in a year (Times) } \\
\hline $1-2$ & \begin{tabular}{|r|}
15.24 \\
\end{tabular} & 9.96 & 6.36 & 6.06 & 5.05 & 13.64 \\
\hline $3-4$ & 52.19 & 47.72 & 61.82 & 48.48 & 45.45 & 36.36 \\
\hline $5-6$ & 28.64 & 29.46 & 26.36 & 39.39 & 44.44 & 40.91 \\
\hline $7-8$ & 2.31 & 10.37 & 5.45 & 6.06 & 5.05 & 9.09 \\
\hline $9-10$ & 0.92 & 2.07 & 0.00 & 0.00 & 0.00 & 0.00 \\
\hline $11-12$ & 0.46 & 0.00 & 0.00 & 0.00 & 0.00 & 0.00 \\
\hline $13-14$ & 0.00 & 0.41 & 0.00 & 0.00 & 0.00 & 0.00 \\
\hline$>14$ & 0.23 & 0.00 & 0.00 & 0.00 & 0.00 & 0.00 \\
\hline \multicolumn{7}{|c|}{ Number of trip mate (Person) } \\
\hline 0 & 29.10 & 46.89 & 32.73 & 27.27 & 22.22 & 31.82 \\
\hline 1 & 38.11 & 29.05 & 51.82 & 35.35 & 34.34 & 31.82 \\
\hline 2 & 21.48 & 17.84 & 14.55 & 29.29 & 34.34 & 31.82 \\
\hline 3 & 5.08 & 4.56 & 0.91 & 7.07 & 9.09 & 0.00 \\
\hline 4 & 3.70 & 1.66 & 0.00 & 1.01 & 0.00 & 4.55 \\
\hline 5 & 0.00 & 0.00 & 0.00 & 0.00 & 0.00 & 0.00 \\
\hline 6 & 0.69 & 0.00 & 0.00 & 0.00 & 0.00 & 0.00 \\
\hline$>6$ & 1.85 & 0.00 & 0.00 & 0.00 & 0.00 & 0.00 \\
\hline \multicolumn{7}{|l|}{ Cabin bag types } \\
\hline Suitcase & 16.40 & 25.73 & 26.36 & 12.12 & 6.06 & 31.82 \\
\hline Backpack & 21.02 & 14.52 & 19.09 & 32.32 & 27.27 & 13.64 \\
\hline Sling & 20.09 & 27.39 & 11.82 & 17.17 & 11.11 & 27.27 \\
\hline Handbag & 40.18 & 31.54 & 42.73 & 30.30 & 38.38 & 18.18 \\
\hline Crackle bag & 0.92 & 0.83 & 0.00 & 8.08 & 7.07 & 4.55 \\
\hline Cardboard & 0.92 & 0.00 & 0.00 & 0.00 & 10.10 & 4.55 \\
\hline & 0.46 & 0.00 & 0.00 & 0.00 & 0.00 & \\
\hline
\end{tabular}

TABLE IV

THE PASSENGER'S BEHAVIORS IN THE AIRPORT TERMINAL

\begin{tabular}{|c|c|c|c|c|c|c|}
\hline \multirow{2}{*}{$\begin{array}{l}\text { Passenger's behaviours } \\
\text { in airport terminal }\end{array}$} & \multicolumn{6}{|c|}{ Percentage of each attributes of the variables for the airlines (\%) } \\
\hline & Lion Air & Garuda & Sriwijaya Air & Citilink & Wings Air & Batik Air \\
\hline \multicolumn{7}{|c|}{ After check in, is passenger direct to waiting room? } \\
\hline Yes & 88.45 & 85.48 & \begin{tabular}{|r|}
90.91 \\
\end{tabular} & 72.73 & 81.82 & 90.91 \\
\hline No & 11.55 & 14.52 & 9.09 & 27.27 & 18.18 & 9.09 \\
\hline \multicolumn{7}{|l|}{ Check-in methods } \\
\hline Online & 27.25 & 43.98 & 0.00 & 26.26 & 0.00 & 40.91 \\
\hline Counter & 69.05 & 53.11 & 98.18 & 67.68 & 97.98 & 50.00 \\
\hline Group & 0.00 & 0.00 & 0.00 & 3.03 & 0.00 & 0.00 \\
\hline Represented & 3.70 & 2.90 & 1.82 & 3.03 & 2.02 & 9.09 \\
\hline \multicolumn{7}{|c|}{ Arrival time headway from boarding time (Minutes) } \\
\hline 30 & 2.31 & 11.20 & \begin{tabular}{|l|l|}
0.00 \\
\end{tabular} & 0.00 & 0.00 & 4.55 \\
\hline $30-60$ & 60.74 & 60.58 & 50.00 & 75.76 & 61.62 & 72.73 \\
\hline $60-90$ & 32.10 & 22.82 & 49.09 & 24.24 & 38.38 & 22.73 \\
\hline & & & & 0.00 & 0.00 & 0.00 \\
\hline $120-150$ & 0.00 & 0.00 & 0.00 & 0.00 & 0.00 & 0.00 \\
\hline$>150$ & 0.00 & 0.00 & 0.00 & 0.00 & 0.00 & 0.00 \\
\hline \multicolumn{7}{|c|}{ Waiting place for boarding time } \\
\hline Public waiting room & 54.27 & 60.58 & 57.27 & 43.43 & 64.65 & 31.82 \\
\hline Café & 38.11 & 10.37 & 30.91 & 41.41 & 29.29 & 45.45 \\
\hline Souvenir shop & 0.00 & 0.00 & 0.91 & 0.00 & 0.00 & 0.00 \\
\hline Place of reflection & 0.00 & 0.00 & 0.00 & 0.00 & 0.00 & 0.00 \\
\hline Around waiting room & 0.00 & 0.41 & 0.00 & 0.00 & 0.00 & 0.00 \\
\hline Lounge & 7.62 & 28.63 & 10.91 & 15.15 & 6.06 & 22.73 \\
\hline Others & 0.00 & 0.00 & 0.00 & 0.00 & 0.00 & 0.00 \\
\hline
\end{tabular}

\section{The Passenger's Perception in Utilizing Public Facilities}

The passenger's perception measurement in term percentage in using public facilities focused on three public places, i.e., public waiting room, café, and lounge. The survey results are shown in Table 5. Table 5 reveals that majority of the passengers stated that public waiting room is sufficient enough until adequate for the passengers. There were around 30\% until 50\% of passengers in each airline which stated their satisfaction. On the other hand, there was a significant amount of the passengers who have an opinion that the public waiting room is less effective. In this regard, there were around $10 \%$ until $20 \%$ of the passengers which have stated their un-satisfaction. Further, there was a similar view of the passengers for the effectiveness of the café facility. Mostly the passengers, around $90 \%$ of passengers stated that the café facility is effective enough until effective. In this regard, only a very small of the passengers stated that the café is less effective, just around 10\%. For lounge facility, a majority of the passenger, around $70 \%$ until $80 \%$ passengers stated that the lounge is also effective enough until effective. However, a significant proportion of the passengers, around $20 \%$ until $30 \%$ of passengers stated that the lounge is less effective. Also, there was a small portion of the passengers, around $5 \%$ of passengers assessed that the lounge is very effective.

\section{E. The Ordered Logit Results for the Passenger's Perception}

The parameters calibration results of the ordered logit models for the three income categories of the passengers of each public facility are shown in Table 6, Table 7, and Table 8 for the public waiting room, café, and lounge facilities, respectively. The three tables show that the maximum likelihood ratio (r) of the models varies from 0.10 until 0.31 . These values indicate that the models have the goodness of fit enough for the parameters values of each model.

TABLE V

THE PASSENGER'S PREFERENCES IN UTILIZING PUBLIC FACILITIES

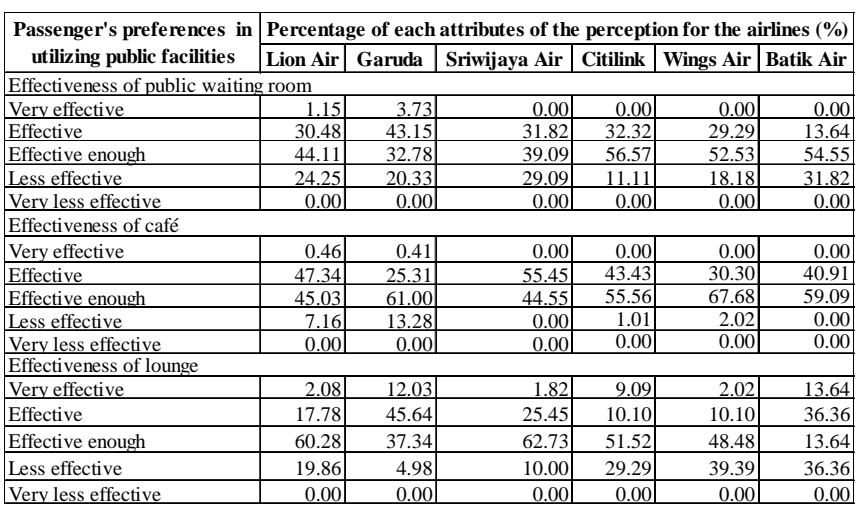

TABLE VI

THE PARAMETERS VALUES OF THE MODEL FOR THE PUBLIC WAITING ROOM

\begin{tabular}{|c|c|c|c|c|c|c|c|}
\hline \multirow{2}{*}{\multicolumn{2}{|c|}{ Variables }} & \multicolumn{2}{|c|}{$<$ IDR $3 \times 10^{6}$} & \multicolumn{2}{|c|}{ IDR 3-4.5 x $10^{6}$} & \multicolumn{2}{|c|}{$>$ IDR $4.5 \times 10^{6}$} \\
\hline & & Coef. & $P>|z|$ & & $\mathrm{P}>|\mathrm{z}|$ & & \\
\hline \begin{tabular}{|l} 
Airlines \\
\end{tabular} & $\mathrm{X}_{1}$ & -0.07 & 0.45 & -0.13 & 0.08 & -0.23 & 0.00 \\
\hline Sex & $\mathrm{X}_{2}$ & -0.51 & 0.13 & 0.58 & 0.01 & 0.32 & 0.26 \\
\hline Occupation & $\mathrm{X}_{3}$ & 0.37 & 0.00 & 0.06 & 0.22 & -0.07 & 0.20 \\
\hline Age & $\mathrm{X}_{4}$ & -0.16 & 0.24 & -0.16 & 0.36 & 0.47 & 0.01 \\
\hline Income & $\mathrm{X}_{5}$ & 2.12 & 0.00 & 0.00 & & 0.04 & 0.83 \\
\hline Pickups & $X_{6}$ & 0.50 & 0.07 & 0.71 & 0.00 & 0.18 & 0.48 \\
\hline Trip purposes & $\mathrm{X}_{7}$ & -0.12 & 0.34 & 0.03 & 0.72 & 0.15 & 0.25 \\
\hline Trip frequency & $\mathrm{X}_{8}$ & 0.35 & 0.03 & 0.36 & 0.09 & -0.17 & 0.22 \\
\hline No. trip mate & $\mathrm{X}_{9}$ & -0.13 & 0.16 & 0.22 & 0.03 & -0.14 & 0.24 \\
\hline Cabin bag types & $\mathrm{X}_{10}$ & -0.20 & 0.04 & 0.06 & 0.47 & -0.31 & 0.00 \\
\hline Direct to waiting room & $\mathrm{X}_{11}$ & $\begin{array}{l}-0.49 \\
\end{array}$ & 0.17 & -0.34 & 0.29 & 0.09 & 0.78 \\
\hline $\begin{array}{l}\text { Check in methods } \\
\end{array}$ & $\mid \begin{array}{l}111 \\
X_{12}\end{array}$ & 0.05 & 0.17 & $\frac{-0.04}{0.24}$ & 0.22 & $\begin{array}{l}0.03 \\
0.03 \\
\end{array}$ & 0.86 \\
\hline Arrival time headway & $\mathrm{X}_{13}$ & \begin{tabular}{ll|}
-1.76 \\
\end{tabular} & 0.00 & -1.84 & 0.00 & \begin{tabular}{|c|}
-1.19 \\
\end{tabular} & 0.00 \\
\hline \begin{tabular}{|l} 
Waiting place for \\
\end{tabular} & $\mathrm{X}_{14}$ & -0.38 & 0.00 & -1.28 & 0.00 & -0.22 & 0.00 \\
\hline Cut1 & $\frac{\lambda_{14}}{\mu_{1}}$ & $\begin{array}{l}-0.00 \\
-1.37 \\
\end{array}$ & & -5.25 & & $\frac{-0.24}{-4.48}$ & \\
\hline Cut2 & $\mu_{2}$ & 0.94 & & -2.79 & & -1.62 & \\
\hline Cut3 & $\mu_{3}$ & & & 0.94 & & 2.38 & \\
\hline Likelihood ratio & $\rho$ & 0.18 & & 0.21 & & 0.12 & \\
\hline
\end{tabular}

The calibration results for the parameters values of the ordered logit model for the public waiting room shows that most variables have influenced the passenger's preferences 
in assessing the effectiveness of the public waiting room facility in the airport for the passenger income category around less than 3 million rupiahs. The variables involve the occupation, income, trip frequency, cabin bag types, checkin methods, the time interval between arrival time and boarding time, and waiting to place for boarding time. For the passenger category of income from three million until four points five million rupiahs, the significant variables which influenced the passenger perception on the effectiveness of the public waiting room to involve sex, pickups available, number of trip mate, the time interval between arrival time and boarding time, and waiting place for boarding time. Furthermore, the passengers who have income more than four point five million rupiahs, have been influenced significantly by airlines types, age, cabin bag types, the time interval between arrival time and boarding time, and waiting place for boarding time on their perception of the effectiveness of the public waiting room. Booth variables, the time interval between arrival time and boarding time, and waiting place for boarding time have significantly influenced on the passenger's perception related to the effectiveness the public waiting room for all passengers' categories.

TABLE VII

THE PARAMETERS VALUES OF THE MODEL FOR THE CAFÉ FACILITY

\begin{tabular}{|c|c|c|c|c|c|c|c|}
\hline \multirow{2}{*}{\multicolumn{2}{|c|}{ Variables }} & \multicolumn{2}{|c|}{$<\operatorname{IDR} 3 \times 10^{6}$} & \multicolumn{2}{|c|}{ IDR $3-4.5 \times 10^{6}$} & \multicolumn{2}{|c|}{$>\operatorname{IDR} 4.5 \times 10^{6}$} \\
\hline & & \begin{tabular}{l|l} 
Coef. \\
\end{tabular} & $\mathrm{P}>|\mathrm{z}|$ & \begin{tabular}{l|l} 
Coef. \\
\end{tabular} & $\mathrm{P}>|\mathrm{z}|$ & \begin{tabular}{l|l} 
Coef. \\
\end{tabular} & $\mathrm{P}>|\mathrm{z}|$ \\
\hline Airlines & $\mathrm{X}_{1}$ & 0.19 & 0.05 & 0.00 & 1.00 & 0.23 & 0.01 \\
\hline Sex & $\mathrm{X}_{2}$ & 0.68 & 0.05 & -0.32 & 0.19 & -0.71 & 0.02 \\
\hline Occupation & $\mathrm{X}_{3}$ & 0.13 & 0.13 & 0.08 & 0.15 & 0.14 & 0.03 \\
\hline Age & $\mathrm{X}_{4}$ & \begin{tabular}{c|c|}
-0.42 \\
\end{tabular} & 0.00 & 0.10 & 0.58 & 0.04 & 0.85 \\
\hline Income & $\mathrm{X}_{5}$ & 0.67 & 0.18 & 0.00 & & -0.44 & 0.01 \\
\hline Pickups & $\mathrm{X}_{6}$ & 0.64 & 0.03 & $\begin{array}{l}-0.16 \\
\end{array}$ & 0.52 & \begin{tabular}{c|c|}
-0.68 \\
\end{tabular} & $\overline{0.02}$ \\
\hline Trip purposes & $\mathrm{X}_{7}$ & -0.20 & 0.14 & -0.04 & 0.67 & \begin{tabular}{|c|c|}
-0.58 \\
\end{tabular} & 0.00 \\
\hline Trip frequency & $\mathrm{X}_{8}$ & 0.56 & 0.00 & -0.05 & 0.80 & 0.57 & 0.00 \\
\hline No. trip mate & $\mathrm{X}_{9}$ & -0.10 & 0.34 & 0.26 & 0.02 & \begin{tabular}{c|c|}
-0.38 \\
\end{tabular} & 0.00 \\
\hline Cabin bag types & $\mathrm{X}_{10}$ & -0.28 & 0.01 & -0.05 & 0.57 & 0.41 & 0.00 \\
\hline Direct to waiting room & $X_{11}$ & -0.08 & 0.84 & -0.28 & 0.40 & 0.59 & 0.10 \\
\hline Check in methods & $X_{12}$ & -0.09 & 0.77 & -0.35 & 0.11 & 0.75 & 0.00 \\
\hline Arrival time headway & $X_{13}$ & -0.58 & 0.03 & 0.10 & 0.59 & 0.18 & 0.42 \\
\hline boarding time & $\mathrm{X}_{14}$ & 0.06 & 0.64 & 1.07 & 0.00 & -0.37 & 0.00 \\
\hline Cut1 & $\mu_{1}$ & -1.05 & & -4.18 & & -3.85 & \\
\hline Cut2 & $\mu_{2}$ & 2.82 & & 1.10 & & \begin{tabular}{c|c|}
-0.69 \\
\end{tabular} & \\
\hline Cut3 & $\mu_{3}$ & & & 7.34 & & 5.37 & \\
\hline Likelihood ratio & $\rho$ & 0.11 & & 0.10 & & 0.21 & \\
\hline
\end{tabular}

TABLE VIII

THE PARAMETERS VALUES OF THE MODEL FOR THE LOUNGE FACILITY

\begin{tabular}{|c|c|c|c|c|c|c|c|}
\hline \multirow{2}{*}{\multicolumn{2}{|c|}{ Variables }} & \multicolumn{2}{|c|}{$<\operatorname{IDR} 3 \times 10^{6}$} & \multicolumn{2}{|c|}{ IDR $3-4.5 \times 10^{6}$} & \multicolumn{2}{|c|}{$>\operatorname{IDR} 4.5 \times 10^{6}$} \\
\hline & & \begin{tabular}{l|l} 
Coef. \\
\end{tabular} & $\mathrm{P}>|\mathrm{z}|$ & Coef. & $\mathrm{P}>|\mathrm{z}|$ & Coef. & $P>|z|$ \\
\hline Airlines & $\mathrm{X}_{1}$ & $\begin{array}{ll}-0.48 \\
\end{array}$ & 0.00 & $\begin{array}{r}-0.73 \\
\end{array}$ & 0.00 & -0.34 & 0.00 \\
\hline Sex & $\mathrm{X}_{2}$ & 0.22 & 0.53 & 0.59 & 0.03 & 0.08 & 0.77 \\
\hline Occupation & $\mathrm{X}_{3}$ & 0.02 & 0.84 & 0.20 & 0.00 & 0.13 & 0.03 \\
\hline Age & $\mathrm{X}_{4}$ & 0.43 & 0.00 & 0.40 & 0.05 & 0.07 & 0.71 \\
\hline Income & $\mathrm{X}_{5}$ & -1.42 & 0.01 & 0.00 & & 0.05 & 0.78 \\
\hline Pickups & $\mathrm{X}_{6}$ & 0.17 & 0.58 & 0.02 & 0.93 & -0.22 & 0.41 \\
\hline Trip purposes & $\mathrm{X}_{7}$ & -0.24 & 0.10 & -0.10 & 0.33 & -0.20 & 0.16 \\
\hline Trip frequency & $\mathrm{X}_{8}$ & 0.74 & 0.00 & 1.10 & 0.00 & 0.75 & 0.00 \\
\hline No. trip mate & $\mathrm{X}_{9}$ & 0.32 & 0.00 & 0.01 & 0.94 & 0.18 & 0.16 \\
\hline Cabin bag types & $\mathrm{X}_{10}$ & -0.22 & 0.04 & -0.30 & 0.00 & 0.10 & 0.31 \\
\hline Direct to waiting room & $\mathrm{X}_{11}$ & -1.55 & 0.00 & -0.84 & 0.02 & 0.16 & 0.63 \\
\hline Check in methods & $\mathrm{X}_{12}$ & 0.77 & 0.01 & 0.66 & 0.01 & -0.29 & 0.08 \\
\hline Arrival time headway & $\mathrm{X}_{13}$ & -0.84 & 0.00 & -0.81 & 0.00 & -0.60 & 0.00 \\
\hline boarding time & $\mathrm{X}_{14}$ & 1.20 & 0.00 & 0.72 & 0.00 & 0.72 & 0.00 \\
\hline Cut1 & $\mu_{I}$ & -2.66 & & -1.01 & & -1.08 & \\
\hline Cut2 & $\mu_{2}$ & 1.46 & & 4.04 & & 2.03 & \\
\hline Cut3 & $\mu_{3}$ & 7.45 & & 8.30 & & 6.14 & \\
\hline Likelihood ratio & $\rho$ & 0.31 & & 0.25 & & 0.29 & \\
\hline
\end{tabular}

On the assessment of the effectiveness of cafe facility, the variables such as airlines, sex, age, pickups available, trip frequency, cabin bag types, and the time interval between arrival time and boarding time, have influenced significantly to the passenger category for income less than three million rupiahs. For the passenger category which has income three million until four points five million rupiahs, the passenger's preferences on the effectiveness of the café, are significantly influenced only by airlines, the number of trip mate, and the place of waiting for boarding time variables. On the other hand, there were many variables have influenced significantly by the passenger's perception of the effectiveness of the cafe' for the passengers which have income more than four point five million rupiahs. The significant variables involved airline, sex, occupation, income, pickups available, trip purposes, trip frequency, the number of trip mate, cabin bag types, check-in methods, and the place of waiting for boarding time. Comprehensively, the airline variable only has a significant influence on the effectiveness of the café facility for the three income categories of the passengers.

The results of the ordered logit model calibration for the effectiveness of lounge facility on Table 8 , showed that many variables had influenced significantly the passenger's preferences for the passenger income category less than three million rupiahs. The variables include airlines, age, income, trip frequency, the number of trip mate, cabin bag types, the activity after check in, check in methods, the time interval between arrival time and boarding time, and the place of waiting for boarding time. The number of significant variables was mostly similar results with the passenger income category for three million until four points five million rupiahs. However, there were additional significant variables such as sex and occupation, as well as; there were excluding variables such as income and number of the trip mate. Furthermore, a small number of variables only has influenced the passenger's preference on the effectiveness of the lounge facility for the passenger income category more than four point five million rupiahs significantly. The variables only involve airlines, occupation, trip frequency, the time interval between arrival time and boarding time, and the place of waiting for boarding time. There are four variables which have influenced the passenger's perception significantly on the effectiveness of the lounge facility for all the passenger income categories, i.e., airlines, trip frequency, the time interval between arrival time and boarding time, and the place of waiting for boarding time.

\section{CONCLUSIONS}

The study has explored the passenger's perception of the effectiveness of the public facilities such as public waiting room, café, and lounge, in Hasanuddin International Airport terminal. According to the calibration results of the parameters values of many variables using the ordered logit models, there are some significant variables which influence the passenger's perception significantly in assessing the effectiveness of the public facilities. The relevant variables involve airlines, trip frequency, the time interval between arrival time and boarding time, and the place of waiting for boarding time.

Briefly, the passenger's perception analyzing described that the public facilities in Hasanuddin International Airport terminal are effective enough. 


\section{REFERENCES}

[1] C.-H. Yeh and Y.-L. Kuo, "Evaluating passenger services of AsiaPacific international airports," Transp. Res. Part E Logist. Transp. Rev., vol. 39, no. 1, pp. 35-48, 2003.

[2] C.-C. Chao, H.-C. Lin, and C.-Y. Chen, "Enhancing airport service quality: A case study of Kaohsiung international airport," J. East. Asia Soc. Transp. Stud., vol. 10, pp. 2235-2254, 2013.

[3] J.-W. Park and J. Se-Yeon, “Transfer passengers' perceptions of airport service quality: A case study of Incheon International Airport," Int. Bus. Res., vol. 4, no. 3, p. 75, 2011.

[4] D. Fodness and B. Murray, "Passengers' expectations of airport service quality," J. Serv. Mark., vol. 21, no. 7, pp. 492-506, 2007.

[5] M. K. Ching, "Passengers' perception on airport service and quality satisfaction," in Proceedings of International Academic Conferences, 2014, no. 201722.

[6] S. A. Adisasmita, "Passenger Perception On Airport Terminal Facilities Performance (Case Study: Soekarno-Hatta International Airport, Indonesia)," Int. J. Eng. Technol. IJET-IJENS IJENS I J E N $S$, vol. 12, no. 2, pp. 1-10, 2012.

[7] S. Han, S. S. Ham, I. Yang, and S. Baek, "Passengers' perceptions of airline lounges: Importance of attributes that determine usage and service quality measurement," Tour. Manag., vol. 33, no. 5, pp. 1103-1111, 2012.

[8] A. G. de Barros, A. K. Somasundaraswaran, and S. C. Wirasinghe, "Evaluation of level of service for transfer passengers at airports," $J$. Air Transp. Manag., vol. 13, no. 5, pp. 293-298, 2007.

[9] M. W. Elias Gonçalves and M. Caetano, "Airport Level of Service: A Model according to Departing Passenger's Perceptions at a Smallsized Airport," J. Airl. Airpt. Manag., vol. 7, no. 1, pp. 65-79, 2017.

[10] G. M. R. Borille and A. R. Correia, "A method for evaluating the level of service arrival components at airports," J. Air Transp. Manag., vol. 27, pp. 5-10, 2013.
[11] W. Jen, M. L. LU, E.-H. Hsieh, Y.-H. Wu, and S.-M. Chan, "Effects of Airport Servicescape on Passengers' Satisfaction: A Hierarchical Approach and Importance-Performance Analysis," J. East. Asia Soc. Transp. Stud., vol. 10, pp. 2223-2234, 2013.

[12] S.-H. Tsaur, T.-Y. Chang, and C.-H. Yen, "The evaluation of airline service quality by fuzzy MCDM," Tour. Manag., vol. 23, no. 2, pp. 107-115, 2002.

[13] W. Li, S. Yu, H. Pei, C. Zhao, and B. Tian, "A hybrid approach based on fuzzy AHP and 2-tuple fuzzy linguistic method for evaluation in-flight service quality," J. Air Transp. Manag., vol. 60, pp. 49-64, 2017.

[14] A. R. Correia, S. C. Wirasinghe, and A. G. de Barros, "A global index for level of service evaluation at airport passenger terminals," Transp. Res. Part E Logist. Transp. Rev., vol. 44, no. 4, pp. 607-620, 2008.

[15] B. Saraswati and S. Hanaoka, "Aviation policy in Indonesia and its relation to ASEAN single aviation market," J. East. Asia Soc. Transp. Stud., vol. 10, pp. 2161-2176, 2013.

[16] S. A. Adisasmita and J. Hadipramana, "Improving the airport operation and environmental quality at small airports in indonesia," Int. J. Sustain. Constr. Eng. Technol., vol. 2, no. 2, 2011.

[17] M. Hustim and K. Fujimoto, "Road Traffic Noise Reduction Using TDM-TMS Strategies In Makassar City, Indonesia," J. Environ. Eng. (Transactions AIJ), vol. 78, no. 689, pp. 551-559, 2013.

[18] M. Hustim, K. Anai, and K. Fujimoto, "Survey on road traffic noise in Makassar City, Indonesia," in INTER-NOISE and NOISE-CON Congress and Conference Proceedings, 2011, vol. 2011, no. 3, pp. 4033-4040.

[19] W. H. Greene, "Econometric analysis (International edition)," 2000. 